\title{
Two Mechanisms for IgG Uptake in Cultured Human Trophoblast: Evidence for a Novel High Affinity Fc Receptor
}

\author{
ABBIE L. ESTERMAN, JOSEPH DANCIS, JEFFREY D. LEE, AND MICHAEL J. RINDLER ${ }^{1}$
}

Departments of Pediatrics (A.L.E., J.D., J.D.L.) and Cell Biology (M.J.R.) and Kaplan Cancer Center

(M.J.R.), New York University School of Medicine, New York, New York 10016 \begin{abstract}
ABST
The mechanism of IgG transport by the placental trophoblast
was examined by studying IgG uptake by purified trophoblast maintained in culture. This model retains the ability to bind and endocytose human IgG from human serum. Comparison of the relative $\mathrm{IgG}$ uptake by the trophoblast among the four subclasses of both human and mouse IgG indicates that the trophoblast IgG receptor has different affinities from those described for the three known human Fc $\gamma$ receptors, FcR $\gamma I$, FcR $\gamma$ II, and FcR $\gamma$ IIII. These results suggest the presence of a novel trophoblast $\mathrm{Fc} \gamma$ receptor. Although Fc $\gamma$ RIII has been reported to be present on trophoblasts, immunocytochemical studies failed to detect binding to the cell surface of antibody-specific for Fc $\gamma$ RIII, $3 G 8 \mathrm{MAb}$. In addition, blocking studies with MAb $3 G 8$ did not interfere with
\end{abstract}

IgG uptake. Scatchard analysis of human IgG uptake revealed a biphasic curve consistent with two distinct mechanisms for the transport of IgG by the trophoblast. The first is a higher affinity system $\left(\mathrm{K}_{\mathrm{a}}=1.7 \times 10^{7} \mathrm{M}^{-1}, 1.7 \times 10^{4}\right.$ binding sites/cell $)$ which exhibits IgG subclass and species specificity, and the second is a low affinity system $\left(\mathrm{K}_{\mathrm{a}}=6.9 \times 10^{3} \mathrm{M}^{-1}, 7.5 \times 10^{7}\right.$ binding sites/cell). (Pediatr Res 38: 1-6, 1995)

\section{Abbreviations}

hIgG, human immunoglobulin $\mathrm{G}$ mIgG, mouse immunoglobulin $\mathrm{G}$ FBS, fetal bovine serum

FCR, antibody binding receptor on the cell membrane
The human fetus acquires antibody as a result of transport of maternal Ig across the placenta (1). This process is selective for the transfer of $\mathrm{IgG}$ - the transfer of IgM and IgA is much less efficient (2). It is generally believed that the transcytosis of $\operatorname{IgG}$ is mediated by $\mathrm{FcR}$ and that $\mathrm{IgG}$ transfer proceeds by a mechanism resembling the transcytosis of IgG in other, better characterized epithelia, such as the neonatal intestine and fetal yolk sac (3-5).

Three classes of Fc $\gamma$ receptors (Fc $\gamma \mathrm{RI}, \mathrm{Fc} \gamma \mathrm{RII}$, and Fc $\gamma \mathrm{RIII})$ have been identified in human leukocytes $(6,7)$. These differ in their affinities for IgG and in their specificity for binding to hIgG and mIgG subclasses. The three types of Fc $\gamma$ receptors have been demonstrated in placental tissues by immunocytochemical techniques $(8-10)$. It has not been established whether any of these $\mathrm{Fc} \gamma$ receptor subtypes mediate the transfer of circulating maternal IgG across the trophoblast.

A trophoblast isolated from the human placenta and maintained in monolayer culture will orient with the microvillous surface facing upward, permitting the investigation of the

Received October 17, 1994; accepted March 16, 1995

Correspondence and reprint requests: Dr. J. Dancis, Department of Pediatrics, New York University School of Medicine, 550 First Avenue, New York, NY 10016.

Supported by NIH grant AI 32298.

${ }^{1}$ M.J.R. is a Crawford-Maynard Established Investigator of the American Heart Association, NYC affiliate. binding and uptake of IgG (11). This model retains many transport functions characteristic of syncytiotrophoblast in vivo as demonstrated in our laboratory and others (12-14). We have used this preparation to study IgG receptor function in differentiated human trophoblasts. The IgG receptors expressed by trophoblasts were characterized functionally by: 1) investigating the specificity of uptake of subclasses of human and mouse IgG and comparing these results with the reported specificities of the Fcy receptors, 2) demonstrating the internalization of IgG by immunocytochemistry, and 3) studying the kinetics of human IgG uptake. We have identified two mechanisms of IgG uptake - a higher affinity system with clear specificity for the IgG subclasses and a less specific low affinity system.

\section{METHODS}

Materials. The sources of the materials were as follows: Medium 199, antibiotics, HEPES, $\gamma$-globulin-free FBS and general tissue culture biologicals were from Life Technologies, Inc. (Grand Island, NY); Percoll from Pharmacia (Piscataway, NJ); keratinocyte medium from Clonetics (San Diego, CA); FBS from Gemini Bioproducts (Calabasas, CA); PlastekC culture plates from Mattek (Ashland, MA); hIgG, hIgG subclasses, bovine IgG, mIgG, lactoperoxidase, Sephadex G-25, trypsin, pancreatin and general laboratory chemicals from 
Sigma (St. Louis, MO); protein A- and protein G-agarose from Boehringer Mannheim (Indianapolis, IN). The mIgG subclasses were obtained from Organon Teknika Corp. (Durham, $\mathrm{NC}) ;\left[{ }^{125} \mathrm{I}\right] \mathrm{NaI}$ and $\left[{ }^{131} \mathrm{I}\right] \mathrm{NaI}$ from Amersham Corp. (Arlington Heights, IL); Dynabeads coated with goat anti-mIgG from Dynal (Lake Success, NY); antibody to CD45 from Becton Dickinson (San Jose, CA). Antibody to cytokeratin was a gift of Dr. T.-T. Sun (NYU Medical Center) and MAb ( $\mathrm{Fab}_{2}$ fragment) directed against Fc $\gamma$ RIII (3G8) was a gift of Dr. J. Unkeless (Mt. Sinai School of Medicine, New York, NY). Affinity-purified rhodamine-conjugated secondary antibodies were purchased from Jackson Immunoresearch (West Grove, PA). Freshly prepared, purified human neutrophils were provided by Dr. M. Philips (NYU Medical Center).

Trophoblast isolation. Human placentas were obtained from noncomplicated full-term pregnancies by either vaginal or cesarean section delivery. The trophoblast was isolated by enzymatic digestion of dissected tissue using a modification of the procedure of Bax et al (15). Briefly, villi were teased apart from connective tissue before digestion in PBS containing 5.5 $\mathrm{mM}$ glucose, $0.33 \mathrm{mM}$ sodium pyruvate, $2 \mathrm{mg} / \mathrm{ml}$ pancreatin, and $2 \mathrm{mg} / \mathrm{ml}$ trypsin. After a first digestion of 35-40 min at $37^{\circ} \mathrm{C}$ with gentle shaking, the tissue was collected by centrifugation, and fresh digestion buffer was added. After incubation for an additional $20-25 \mathrm{~min}$, the trophoblast was released into the supernatant by vigorous shaking, and then passed sequentially through one, two, and three layers of sterile surgical gauze. The cells were pelleted and centrifuged through a discontinuous Percoll gradient as described by Kliman et al. (12). The recovered trophoblast was passed sequentially through 250 - and $100-\mu \mathrm{m}$ nylon mesh. In some experiments (as indicated in the text), the isolated cells were incubated with mouse-anti CD45 antibody, and the macrophage cells were removed by magnetic microspheres coated with goat-anti$\mathrm{mIgG}$ as described by Douglas and King (16). The resulting purified trophoblast was $>99 \%$ cytokeratin positive, whereas $<0.4 \%$ of the cells were positive for CD45 as demonstrated by immunofluorescence. The trophoblast was plated in Medium 199 containing $15 \%$ FBS and antibiotics at a density of $4 \times 10^{5}$ cells $/ \mathrm{cm}^{2}$ on Mattek C culture dishes. Fungizone $(2 \mu \mathrm{g} / \mathrm{ml})$ was included when placentas were obtained from vaginal deliveries. After attachment overnight, the cultures were washed with PBS and fed with keratinocyte medium containing $10 \%$ $\gamma$-globulin-free FBS and antibiotics (KBM) as described by Douglas and King (17). IgG uptake assays were done after $48-72 \mathrm{~h}$ of culture.

Binding and uptake of IgG by trophoblast. Ig was iodinated by the lactoperoxidase method with $\left[{ }^{125} \mathrm{I}\right] \mathrm{NaI}$ or $\left[{ }^{131} \mathrm{I}\right] \mathrm{NaI}$ as described by Kadner et al. (18). The radiolabeled IgG was separated from free iodine by passage through a Sephadex G25 column. Before each experiment the radiolabeled $\operatorname{IgG}$ was determined to be $>98 \%$ intact protein by spin filtration using the Centrifree Micropartition System (Amicon, Beverly, MA). Protein integrity was also checked by SDS-polyacrylamide gel electrophoresis and by binding to protein A- or protein Gagarose.

The trophoblast was incubated with $\mathrm{KBM}$ containing $25 \mathrm{mM}$ HEPES and $5 \times 10^{5}$ to $1.5 \times 10^{6} \mathrm{cpm} / \mathrm{ml}$ labeled IgG (sp act $\left.1-2 \times 10^{6} \mathrm{cpm} / \mu \mathrm{g}\right)$ at either 37 or $4^{\circ} \mathrm{C}$. The cultures were washed five times with cold PBS, and the cells lysed with $1 \%$ SDS, $10 \mathrm{mM}$ Tris, $1 \mathrm{mM}$ EDTA. Lysates were collected, and the radioactivity was measured using a Packard Cobra AutoGamma counter. For kinetic studies increasing amounts of unlabeled hIgG were added to the incubation medium. For studies of IgG subclass discrimination by the low affinity system, $10 \mathrm{mg} / \mathrm{ml} \mathrm{hIgG}$ was added to the incubation medium.

Immunofluorescence microscopy. Cells were grown for 3-4 days on $12-\mathrm{mm}$ glass coverslips coated with $1 \mu \mathrm{g} / \mathrm{cm}^{2}$ fibronectin (Sigma). For detection of cytoskeletal proteins (e.g. cytokeratin) or the macrophage marker CD45, cells were fixed for 5-7 min in ice-cold methanol. For detection of alkaline phosphatase and $3 G 8$, the cells were fixed in $4 \%$ paraformaldehyde in PBS for $30 \mathrm{~min}$ as previously described (19). The fixed coverslips were incubated with or without $0.1 \%$ Triton100 for $5 \mathrm{~min}$ and then for $1-3 \mathrm{~h}$ with antibodies at a $1: 50$ to 1:100 dilution followed by rhodamine-conjugated goat antirabbit or mouse IgG (Jackson Immunoresearch, West Grove, PA), as appropriate. The detergent treatment did not affect the overall staining patterns. When the uptake of IgG was measured, specimens were fixed in paraformaldehyde after the incubation period and then permeabilized with $0.2 \%$ Triton $\mathrm{X}-100$. A rhodamine-conjugated goat anti-hIgG was then used in a single labeling step. Preparations were viewed and photographed on a Zeiss Axiophot microscope.

\section{RESULTS}

Uptake of IgG by cultured trophoblast. The uptake of IgG was studied using an isolated trophoblast prepared by standard procedures (see "Methods"). As determined by immunofluorescence staining with antibodies to cytokeratin and placental alkaline phosphatase, the trophoblast population was $>97 \%$ pure. The cells were cultured for $72 \mathrm{~h}$ in keratinocyte medium to permit them to differentiate into large multinucleate cells which exhibit a syncytiotrophoblast phenotype. At this time, large amounts of human chorionic gonadotropin and progesterone are produced by the cells as reported by Kliman et al. (12) and confirmed by our laboratory (14). Electron microscopic examination of the cells revealed microvilli on the free surface with enlarged endoplasmic reticulum and numerous mitochondria (data not shown).

To confirm the appropriateness of the experimental model, the cells were incubated with human serum at 4 or $37^{\circ} \mathrm{C}$, and the IgG was visualized by immunofluorescence microscopy (Fig. 1). At $4^{\circ} \mathrm{C}, \operatorname{lgG}$ binding to the cell membrane was detected as uniform surface staining with some areas having a more punctate appearance. At $37^{\circ} \mathrm{C}$, all of the cells were brightly stained with $\operatorname{IgG}$ on both the cell surface and in large vesicles, taken to be endosomes, indicating that internalization of $\mathrm{IgG}$ is a property that is maintained by the trophoblast in culture.

The species specificity of $\operatorname{IgG}$ uptake was investigated using radioiodinated IgG to provide additional evidence that the cultured trophoblast model maintained the properties of syncytiotrophoblast in native tissue. hIgG was taken up by the cells in a time-dependent manner (Fig. 2). Incubation in the 

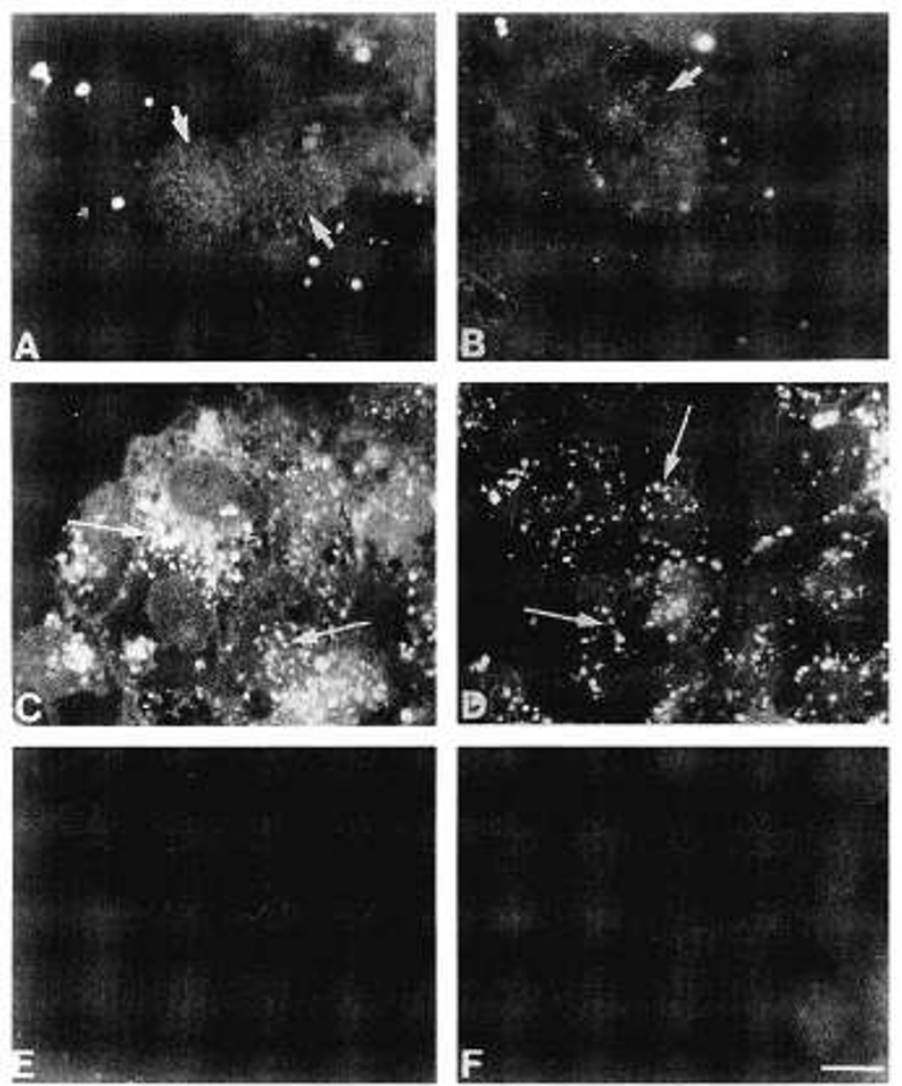

Figure 1. Internalization of $\mathrm{hIgG}$ by a cultured trophoblast. An isolated trophoblast free of Hofbauer cells was cultured on fibronectin-coated glass coverslips for $72 \mathrm{~h}$ and then incubated for $2 \mathrm{~h}$ in the presence $(A-D)$ or absence ( $E$ and $F$ ) of human serum at either 37 or $4^{\circ} \mathrm{C}$. The cells were fixed and reacted with rhodamine-conjugated goat anti-hIgG antibody as described in "Methods." hIgG binding to the cell membrane at $4^{\circ} \mathrm{C}$ (panels $A$ and $B$ ) is visualized as uniform surface staining with some areas having a more punctate appearance (arrows). At $37^{\circ} \mathrm{C}$ (panels $C$ and $D$ ) the cells are brightly stained with $\operatorname{IgG}$ present both on the cell surface and in large vesicles (arrows). Control cultures incubated in the absence of human serum at $4^{\circ} \mathrm{C}$ (panel E) or $37^{\circ} \mathrm{C}$ (panel $F$ ) showed only a low level diffuse staining of the nuclei. Bar $=8 \mu \mathrm{M}$.

presence of excess $\mathrm{hIgG}(10 \mathrm{mg} / \mathrm{ml})$ reduced, by $\sim 60 \%$, the uptake of hIgG by trophoblast. By comparison, bovine $\operatorname{IgG}$ uptake was 30\% that of hIgG and was not reduced in the presence of excess hIgG. These results are consistent with qualitative immunohistochemical observations made on cryostat sections of human placental villous tissue where the binding of $\mathrm{hIgG}$ to the trophoblast was not blocked with bovine IgG (20) and perfusion studies where hIgG was transferred across the placenta approximately 3 -fold more rapidly than bovine $\operatorname{IgG}(21)$. The uptake of $\mathrm{mIgG}$ was also measured and found to be similar in magnitude to the uptake of hIgG (Fig. 2). Addition of excess unlabeled hIgG during the 120-min uptake period reduced the amount of ${ }^{125}$ I-labeled $\mathrm{mIgG}$ associated with the cells to the same extent as it did the uptake of hIgG (data not shown).

Uptake of IgG subclasses. IgG receptors can be classified by the relative rates of uptake of the four subclasses of hIgG. hIgG subclasses were incubated with the trophoblast cells for up to $2 \mathrm{~h}$ using our standard assay conditions. As can be seen in Figure 3, IgG1 and IgG3 were taken up well, at a rate comparable to complete human $\operatorname{IgG}$. IgG2 and IgG4 are taken up

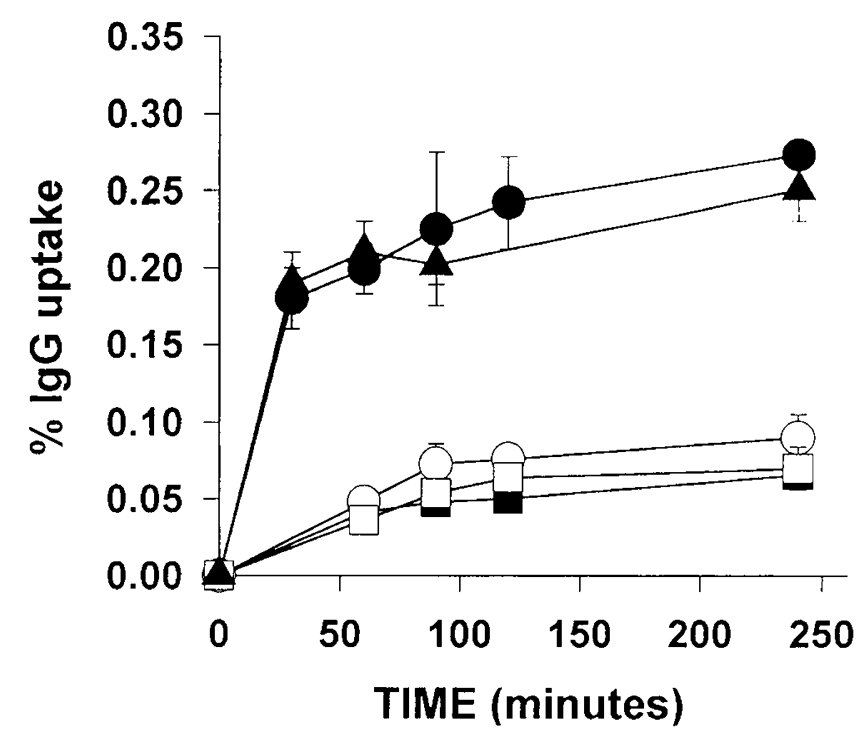

Figure 2. Human, mouse, and bovine IgG uptake by the human trophoblast. An isolated trophoblast was cultured for $72 \mathrm{~h}$. Uptake studies were performed in triplicate with either ${ }^{125} \mathrm{I}$-labeled human and ${ }^{131}$ I-labeled bovine IgG \pm 10 $\mathrm{mg} / \mathrm{ml} \mathrm{hIgG}$ or ${ }^{125} \mathrm{I}$-labeled $\mathrm{mIgG}$ alone for the indicated times as described in "Methods." The data shown are the results obtained from trophoblast isolated from one placenta and are representative of three different trophoblast preparations from three placentas.,${ }^{125} \mathrm{I}$-labeled hIgG; $\mathrm{O},{ }^{125} \mathrm{I}$-labeled hIgG +10 $\mathrm{mg} / \mathrm{ml} \mathrm{hIgG;} \mathbf{\Delta},{ }^{125} \mathrm{I}$-labeled mIgG; $\mathbf{\square},{ }^{131}$ I-labeled bovine IgG; $\square,{ }^{131}$ I-labeled bovine $\mathrm{IgG}+10 \mathrm{mg} / \mathrm{ml} \mathrm{hIgG}$.

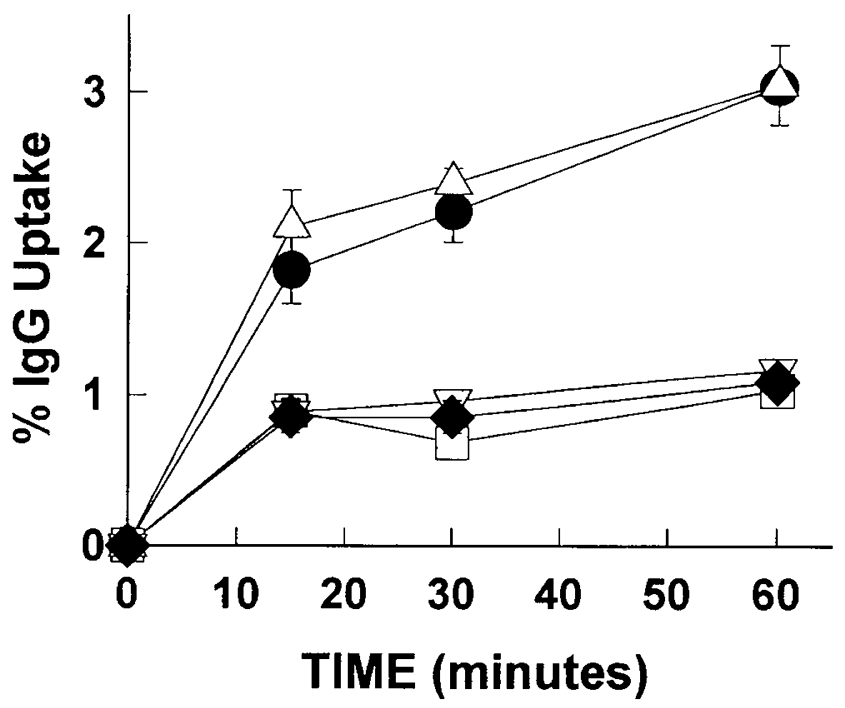

Figure 3. Uptake of hlgG subclasses. A trophoblast isolated free from Hofbauer cells and cultured as described in "Methods" was incubated with ${ }^{131}$ I-labeled bovine IgG and ${ }^{125}$ I-labeled hIgG1, hIgG2, hIgG3, or hIgG4 for the times indicated. The data shown are the results obtained from trophoblast isolated from one placenta and are representative of three trophoblast preparations from three placentas. The error bars are derived from the values obtained from triplicate wells. $\bullet, \operatorname{IgG} 1 ; \square, \operatorname{IgG} 2 ; \triangle, \operatorname{IgG} 3 ; \nabla, \operatorname{IgG} 4 ; \diamond$, bovine IgG.

poorly, similar in magnitude to bovine IgG. In these experiments, Hofbauer cell-free trophoblast cultures were used (see "Methods"). However, removal of Hofbauer cells did not affect the relative rates of uptake of the four subclasses of hIgG (data not shown). The relative avidities for the subclasses (hIgG3, hIgG1 >> hIgG2, hIgG4 = bovine IgG) are the same as the reported specificities of the Fc $\gamma$ RIIaHR (22) and FcyRIII (6) 
receptors but are different from that of Fc $\gamma$ RIIaLR (hIgG3 >hIgG1, hIgG2 >> hIgG4) (22) and Fc $\gamma$ RI (hIgG1 > hIgG3 $>$ hIgG4 $>>$ hIgG2) (23).

Human Fc $\gamma$ RII and Fc $\gamma$ RIII can be differentiated by their avidities for mIgG subclasses: $\mathrm{hFc} \gamma \mathrm{RII}-\mathrm{mIgG} 1, \mathrm{mIgG} 2 \mathrm{~b}>>$ mIgG2a, mIgG3 and hFc $\gamma$ RIII-mIgG3 $>$ mIgG2a $>$ mIgG2b $>>$ mIgG1 (24). Shown in Figure 4 is a comparison of the uptake of the mouse IgG subclasses by the cultured human trophoblast. The relative uptake specificity for the subclasses was $\mathrm{mIgG} 3>>\mathrm{mIgG} 1, \mathrm{mIgG} 2 \mathrm{a}$, and $\mathrm{mIgG} 2 \mathrm{~b}=$ bovine IgG. The observed hierarchy of mouse $\operatorname{IgG}$ subclass specificity suggests that the IgG receptor expressed by trophoblast is a novel receptor, differing functionally from all of the known $\mathrm{Fc} \gamma \mathrm{R}$ receptors.

Fc $\gamma$ RIII receptors have been reported on the human trophoblast in the placenta using immunologic techniques (see "Discussion"). We investigated the possible presence of Fc $\gamma$ RIII on cultured trophoblast using a MAb $3 G 8$, which is specific for $\mathrm{Fc} \gamma \mathrm{RIII}$ and blocks IgG binding to neutrophils which express Fc $\gamma$ III $(25,26)$. After incubation of isolated neutrophils with $3 G 8$ antibody and fluorescent-conjugated secondary antibodies, bright staining was observed over the entire cell surface, confirming the reactivity of this antibody with Fc $\gamma$ RIII receptors (data not shown). By contrast, there was no specific staining with trophoblast. In blocking studies with $3 G 8$ antibody, trophoblast was incubated with Fab2 fragments in high concentrations before and during incubation with ${ }^{125}$ I-labeled hIgG. No significant decrease in uptake of human IgG by trophoblast was observed (data not shown).

Kinetics of IgG uptake. To further characterize the trophoblast IgG receptors, we determined the association constant $\left(\mathrm{K}_{\mathrm{a}}\right)$ and number of binding sites on trophoblast. The cells were incubated with increasing concentrations of hIgG, and the data were then subjected to Scatchard analysis. For these studies only purified cells, Hofbauer-free, were used. A biphasic curve is evident indicating the existence of two IgG receptors (Fig. 5). The first is a higher affinity, low capacity system with a $K_{a}$ of $1.7 \times 10^{7} \mathrm{M}^{-1}$ and $1.7 \times 10^{4}$ binding sites per cell. The

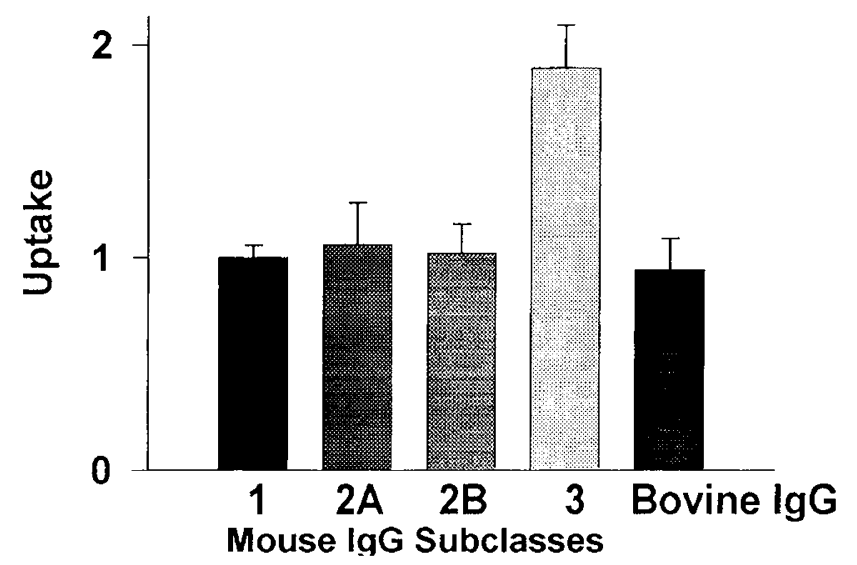

Figure 4. Uptake of $\mathrm{mIgG}$ subclasses. Trophoblast was incubated with ${ }^{131} \mathrm{I}$ labeled bovine IgG and ${ }^{125}$ I-labeled mIgG1, mIgG2A, mIgG2B, or mIgG3 for $2 \mathrm{~h}$ as described in "Methods." The data are expressed as the relative amount of mouse subclass IgG uptake compared with the uptake of mIgG1. IgG1 has been given a value of 1 . The results presented are the mean \pm SD from data obtained from trophoblast preparations from four placentas.

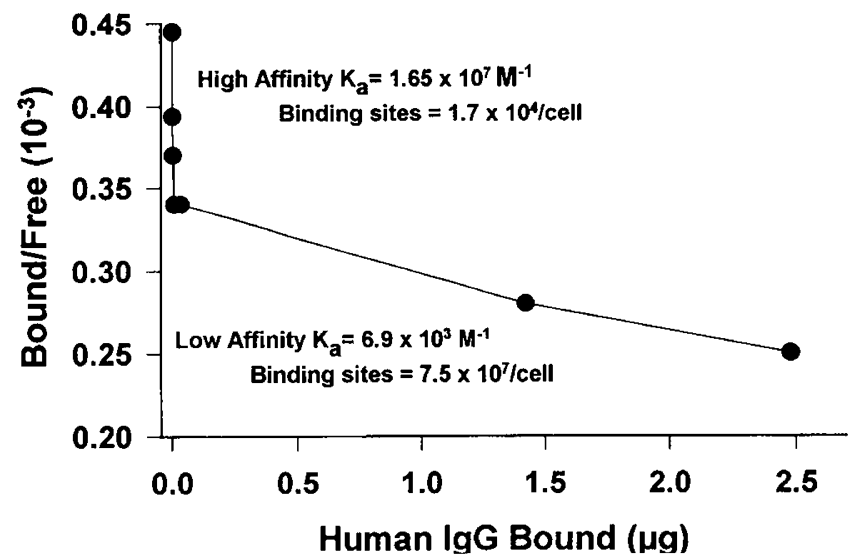

Figure 5. Kinetic analysis of hIgG uptake. An isolated trophoblast free of macrophage (Hofbauer cell) contamination was cultured for $72 \mathrm{~h}$ and then for $2 \mathrm{~h}$ in the presence of ${ }^{125} \mathrm{I}$-labeled $\mathrm{hIgG}$ with increasing concentrations of unlabeled hIgG. The radioactivity associated with the cells was determined as described in "Methods." The amount of IgG bound to the cells was calculated for each concentration and depicted as a Scatchard plot (bound/free vs bound IgG). A biphasic curve was evident and the corresponding association constants $\left(\mathrm{K}_{\mathrm{a}}\right)$ and the number of binding sites were calculated from the plot for both the high and low affinity systems. The data shown are the results obtained from a trophoblast isolated from one placenta and are representative of three different placentas.

second is a low affinity, high capacity system with a measurable $\mathrm{K}_{\mathrm{a}}$ of $6.9 \times 10^{3} \mathrm{M}^{-1}$ and $7.5 \times 10^{7}$ binding sites per cell.

The ability of the two transport mechanisms to discriminate between the four subclasses of hIgG was also compared (Fig. 6). The higher affinity mechanism was investigated by incubating the trophoblast cells with $3 \mu \mathrm{g} / \mathrm{ml}$ human radioiodinated $\mathrm{IgG}$ subclasses for $2 \mathrm{~h}$. The low affinity system was assayed by measuring uptake of the subclasses in the presence of $10 \mathrm{mg} / \mathrm{ml}$ hIgG. The higher affinity receptor clearly is able to differentiate between the four hIgG subclasses and bovine $\operatorname{IgG}$ as was observed in Figure 3, whereas the low affinity system is not.

\section{DISCUSSION}

MAb directed against the three classical Fc $\gamma \mathrm{R}$ have been used to attempt to identify placental IgG receptors. These studies clearly demonstrated that Fc $\gamma \mathrm{RI}$ is absent from the trophoblast but is associated with the stromal cells, including Hofbauer cells (8-10). Fc $\gamma$ RII is expressed by the endothelium and on stromal cells. In one study Fc $\gamma$ RII was also localized to the trophoblast layer in hydatidiform mole and its mRNA was detected in cultures of enriched trophoblast (27). It is possible that the Northern blotting technique used in this study was sufficiently sensitive to detect $\mathrm{Fc} \gamma \mathrm{RII}$ receptors on contaminating Hofbauer cells. Fc $\gamma$ RII receptors have not been identified on purified trophoblast. The presence of Fc $\gamma$ RIII on trophoblast has been controversial. Fc $\gamma$ RIII has been reported to be present on trophoblast by flow cytometry on isolated cytotrophoblast (28) and by immunocytochemistry on placental sections $(8,9)$. However, in agreement with our immunolocalization results, Wainwright and Holmes (29) reported that antibodies to FcyRIII which react with Hofbauer cells from term placenta failed to show any reactivity with placental term trophoblasts. 


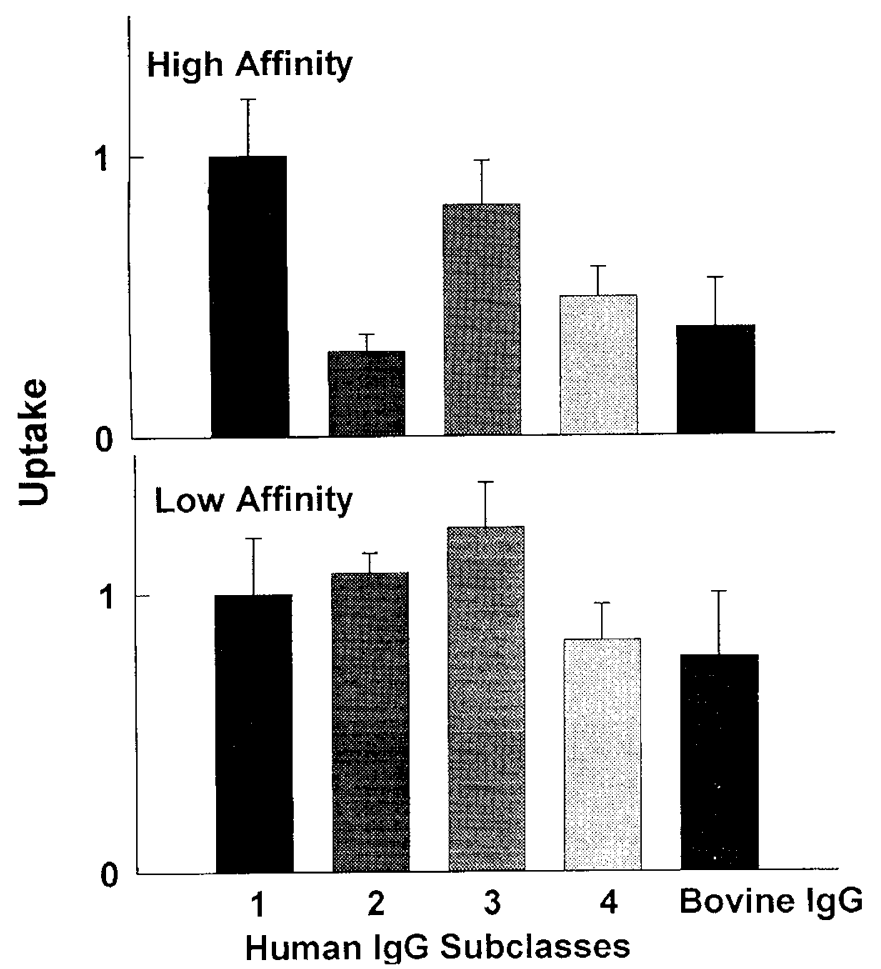

Figure 6. Discrimination of the hIgG subclasses by the high affinity and low affinity mechanisms. To measure the high affinity mechanism, isolated trophoblast was cultured for $72 \mathrm{~h}$ and incubated with $3 \mu \mathrm{g} / \mathrm{ml}{ }^{125} \mathrm{I}$-labeled hIgG1, hIgG2, hIgG3, or hIgG4 and ${ }^{131}$ I-labeled bovine IgG for $2 \mathrm{~h}$. To assay the low affinity system, cultured trophoblast was incubated as above with the addition of $10 \mathrm{mg} / \mathrm{ml} \mathrm{hIgG}$. The relative uptake for each subclass was determined by comparing the uptake of each subclass to the uptake of IgG1, which was given a value of 1 . The results presented are the mean \pm SD from data obtained from a trophoblast isolated from four different placentas.

Despite the reports of the presence of receptors on trophoblasts that react with MAb against Fc $\gamma$ RII and Fc $\gamma$ RIII, the involvement of these receptors in the transport of $\operatorname{IgG}$ has not been established. In the present study, we have characterized the receptors by their transport function as expressed by the relative affinities for the subclasses of $\mathrm{hIgG}$ and $\mathrm{mIgG}$. By using highly purified trophoblast preparations we were able to measure the properties of the receptors of the syncytiotrophoblast itself. The cultured trophoblast preparation retains the ability to bind and endocytose IgG from human serum (Fig. 1). The relative affinities of the trophoblast higher affinity receptor for the four subclasses of human and mouse IgG exclude functional identity with any of the known human Fc $\gamma$ R.

Because of the reports in the literature of the presence of Fc $\gamma$ RIII receptors on trophoblast $(8,9,30)$ we investigated the possible involvement of Fc $\gamma$ RIII using a MAb specific for Fc $\gamma$ RIII, $3 G 8$. Preincubation of trophoblast with $3 G 8$ did not inhibit the uptake of $\operatorname{IgG}$, although it is known to effectively block the uptake of IgG by neutrophils $(25,26)$. Furthermore, as assessed by immunofluorescence microscopy, the antibody failed to bind to cultured trophoblast. These results exclude the functional involvement of the Fc $\gamma$ RIII receptors in the uptake of IgG, and support the conclusion that the trophoblast receptor is novel. Our results do not completely rule out the possibility that novel, alternatively spliced forms of Fc $\gamma$ RII or Fc $\gamma$ RIII could be responsible for the observed higher affinity uptake of IgG. However, for Fc $\gamma$ RII, all of the known allotypic forms have identical or nearly identical extracellular domains that are not distinguishable by MAb $(6,22)$. Similarly, the two Fc $\gamma$ RIII allotypic forms differ only in their mode of membrane association, with Fc $\gamma$ RIIIB being glycosyl phosphatidyl inositol linked. Neither form binds monomeric IgG with high affinity. Fc $\gamma$ RIIIA forms multimeric complexes with Fc $\epsilon$ RI $\gamma$ and/or $\mathrm{CD} 3 / \mathrm{TcR} \zeta$ chains (6). It is not known if other forms of these accessory subunits exist in the trophoblast that may alter the specificity and affinity of Fc $\gamma$ RIIIA. However, the lack of binding of mAb $3 G 8$ tends to rule out this possibility as well.

Scatchard analysis of IgG transport yielded biphasic kinetics, indicating that the trophoblast has two receptors for IgG uptake. The first corresponds to a single higher affinity receptor $\left(\mathrm{K}_{\mathrm{a}} \sim 1.7 \times 10^{7} \mathrm{M}^{-1}\right)$ that discriminates between the four subclasses of human and mouse $\mathrm{IgG}$. The second represents a low affinity mechanism $\left(\mathrm{K}_{\mathrm{a}} \sim 7 \times 10^{4} \mathrm{M}^{-1}\right)$ that does not discriminate among any of the different $\mathrm{IgG}$ used in this study. Kinetic studies have also been conducted by other investigators using isolated placental membranes with reported $\mathrm{K}_{\mathrm{a}}$ values of $8.6 \times 10^{6}(30), 4 \times 10^{7}(31)$, and $4 \times 10^{6} \mathrm{M}^{-1}(32)$. Studies of Rees and Wallace (33) and Lubega (34) both presented evidence of biphasic kinetics of $\operatorname{IgG}$ uptake, suggesting that low and high affinity IgG receptors were present. However, all of the previous studies were performed on membrane preparations from placenta, which contains many cell types including the Hofbauer cells which express FcR. In the kinetic studies that we have performed, the trophoblast was $>99 \%$ pure with Hofbauer cells removed, permitting the conclusion that trophoblast has both a high and low affinity mechanism for IgG uptake.

Two additional proteins have been suggested as the placental IgG receptors. Matre et al. (35), using affinity chromatography, isolated a $40-\mathrm{kD}$ protein, which was present on the microvillous membrane of the syncytiotrophoblast. Binding studies showed the human subclass specificity of this receptor to be hIgG1, hIgG3 >> hIgG2, hIgG4. The affinities for the mouse subclasses of IgG have not been determined, leaving open the question as to whether the receptor is the same as the one that we have studied. Makiya and Stigbrand (36) have provided evidence that alkaline phosphatase, which is abundant on the apical membrane of syncytiotrophoblast, can serve as an IgG receptor. However, the reported $\mathrm{K}_{\mathrm{a}}$ of alkaline phosphatase for human IgG was $3.7 \times 10^{6} \mathrm{M}^{-1}$, far lower than that we have observed for the high affinity system $\left(1.7 \times 10^{7} \mathrm{M}^{-1}\right)$.

The placenta in vivo is exposed to maternal concentrations of IgG $(10 \mathrm{~g} / \mathrm{L})$ that would allow both transport systems to function in the initial binding of $\operatorname{IgG}$ and its uptake into the syncytiotrophoblast. If both systems contribute to the transcytosis of $\operatorname{IgG}$, the present studies would suggest that the four subclasses would be transferred to the fetus with a selective advantage for IgG1 and IgG3. Analyses of cord serum (37) have shown IgG1 in higher concentration than in maternal serum $(10.89 \mathrm{~g} / \mathrm{L}$ versus $6.65 \mathrm{~g} / \mathrm{L})$ and $\mathrm{IgG} 2$ in lower concentration (2.65 versus 1.58$)$, consistent with their relative rates of uptake by trophoblast. However, the reported concentrations of $\operatorname{IgG} 3(0.56 \mathrm{~g} / \mathrm{L}$ versus $0.45 \mathrm{~g} / \mathrm{L})$ and $\operatorname{IgG} 4(0.43 \mathrm{~g} / \mathrm{L}$ versus 
$0.35 \mathrm{~g} / \mathrm{L}$ ) are not significantly different in the fetal and maternal circulations despite the apparent differences in their uptake by the cultured trophoblast. The efficiency of uptake may not accurately reflect the efficiency of maternal-fetal transfer across the placenta, and additional factors such as the half-life of transferred proteins in the fetal circulation may play a role in determining the circulating concentrations.

$\operatorname{IgG}$ is the only circulating maternal protein known to be specifically and preferentially transferred across the placenta. It is important to note, however, that several other maternal blood proteins, for which specific transport mechanisms have not been identified, including albumin, IgM, and ceruloplasmin, are transferred into the fetal circulation and are present at levels that, although not nearly equal to those in maternal blood, are nonetheless substantial (38). The low affinity IgG uptake system that is described in this study appears to have high capacity and lacks the ability to discriminate among IgG subclasses. We suggest that this system may not be specific for IgG but may also function for the uptake of other proteins as well. Some of this "nonspecific" uptake may result in the transfer of maternal proteins across the trophoblast to the fetal circulation, although this process is probably not very efficient. In this way, the trophoblast would to some degree resemble endothelial cells, which are responsible for the transfer of proteins from the blood to the interstitial fluid.

Note Added in Proof. C.M. Story, J.E. Mikulska, and N.E. Simister (Journal of Experimental Medicine (1994) 180:237781) have recently reported a receptor cloned from a cDNA library of human term placenta that is homologous to mouse and rat intestinal Fc receptors. Transfected cells bound human Fc effectively at $\mathrm{pH} 6.0$ and very modestly at $\mathrm{pH} 7.5$.

\section{REFERENCES}

1. Dancis J, Lind J, Oratz M, Smolens J, Vara P 1961 Placental transfer of proteins in human gestation. Am J Obstet Gynecol 82:167-171

2. Gitlin D, Kumate J, Urrusti J, Morales C 1964 The selectivity of the human placenta in the transfer of plasma proteins from mother to fetus. J Clin Invest 43:1938-1951

3. Abrahamson DR, Rodewald R 1981 Evidence for the sorting of endocytic vesicle contents during the receptor-mediated transport of IgG across the newborn rat intestine. J Cell Biol 91:270-280

4. Simister NE, Mostov KE 1989 An Fc receptor structurally related to MHC class I antigens. Nature 337:184-187

5. Roberts DM, Guenthert M, Rodewald R 1990 Isolation and characterization of the Fc receptor from fetal yolk sac of the rat. J Cell Biol 111:1867-1876

6. Ravetch JV, Kinet J-P 1991 Fc Receptors. Annu Rev Immunol 9:457-92

7. Unkeless JC, Scigliano E, Freedman VH 1988 Structure and function of human and murine receptors for IgG. Annu Rev Immunol 6:251-281

8. Kristoffersen EK, Ulvestad E, Vedeler CA, Matre R 1990 Fc $\gamma$ receptor heterogeneity in the human placenta. Scand J Immunol 31:561-564

9. Kameda T, Koyama M, Matsuzaki N, Taniguchi T, Saji F, Tanizawa O 1991 Localization of three subtypes of $\mathrm{Fc} \gamma$ receptors in human placenta by immunohistochemical analysis. Placenta 12:15-26

10. Sedmak DD, Davis DH, Singh U, van de Winkel JGJ, Anderson CL 1991 Expression of $\mathrm{IgG}$ receptor antigens in placenta and on endothelial cells in humans. Am J Pathol 130:175-181

11. Sooranna SR, Contractor SF 1990 Binding and internalization of immunoglobulin G by cultured human trophoblast. J Dev Physiol 13:333-338

12. Kliman HJ, Nestler JE, Sermasi E, Sanger JM, Strauss III JF 1986 Purification, characterization, and in vitro differentiation of cytotrophoblasts from human term placentae. Endocrinology 118:1567-1582
13. Bullen BE, Bloxam DL, Ryder TA, Mobberley MA, Bax CMR 1990 Two-sided culture of human placental trophoblast. Morphology, immunocytochemistry and permeability properties. Placenta 11:431-450

14. Esterman AL, Rosenberg C, Brown T, Dancis J 1995 The effect of zidovudine and 2'3'dideoxyinosine on human trophoblast in culture. Pharmacol Toxicol 76:89-92

15. Bax CMR, Ryder TA, Mobberley MA, Tyms AS, Taylor DL, Bloxam DL 1989 Ultrastructural changes and immunocytochemical analysis of human placental trophoblast during short-term culture. Placenta 10:179-194

16. Douglas GC, King BF 1989 Isolation of pure villous cytotrophoblast from term human placenta using immunomagnetic microspheres. J Immunol Methods 119:259268

17. Douglas GC, King BF 1990 Differentiation of human trophoblast cells in vitro as revealed by immunocytochemical staining of desmoplakin and nuclei. J Cell Sci 96:131-141

18. Kadner SS, Katz J, Berliner BA, Levitz M, Finlay TH 1984 Hormonally sensitive esterase activity in the mouse uterus results from uptake of plasma esterase. Endocrinology 155:2406-2417

19. Rindler MJ, Ivanov IE, Plesken H, Rodriguez-Boulan E, Sabatini DD 1984 Viral glycoproteins destined for apical or basolateral plasma membrane domains traverse the same Golgi apparatus during their intracellular transport in doubly infected Madin-Darby canine kidney cells. J Cell Biol 98:1304-1319

20. Johnson PM, Falk WP, Wang A-C 1976 Immunological studies of human placentae: subclass and fragment specificity of aggregated IGg by human endothelial cells. Immunology 31:659-664

21. Contractor SF, Eaton BM, Stannard PJ 1983 Uptake and fate of exogenous immunoglobulin $G$ in the perfused human placenta. J Reprod Immunol 5:265-273

22. Parren PW, Warmerdam PA, Boeije LC, Arts J, Westerdaal NA, Vlug A, Capel PJ, Aarden LA, van de Winkel JG 1992 On the interaction of IgG subclasses with the low affinity Fc gamma RIIa (CD32) on human monocytes, neutrophils and platelets. Analysis of a functional polymorphism to human IgG2. J Clin Invest 90:1537-1546

23. Huber H, Douglas SD, Nusbacher J, Kochwa S, Rosenfield RE 1971 IgG subclass specificity of human monocyte receptor sites. Nature 229:419-420

24. Anasetti C, Martin PJ, Morishata Y, Badger CC, Bernstein ID, Hansen JA 1987 Human large granular lymphocytes express high affinity receptors for murine monoclonal antibodies of the IgG3 subclass. J Immunol 138:2979-2981

25. Salman JE, Kapur S, Kimberly RP 1987 Opsonin-independent ligation of Fc gamma receptors. The $3 G 8$-bearing receptors on neutrophils mediate the phagocytosis of concanavalin A-treated erythrocytes and nonopsonized Escherichia coli. J Exp Med 166:1798-7813

26. Fleit HB, Wright SD, Unkeless JC 1982 Human neutrophil Fc gamma receptor distribution and structure. Proc Natl Acad Sci USA 79:3275-3279

27. Stuart SG, Simister NE, Clarkson SB, Kacinski BM, Shapiro M, Mellman I 1989 Human IgG Fc receptor (hFcRII; CD32) exists as multiple isoforms in macrophages, lymphocytes and IgG-transporting placental epithelium. EMBO J 8:3657-3666

28. Nishikiori N, Koyama M, Kikuchi T, Kimura T, Ozaki M, Harada S, Saji F, Tanizawa O 1993 Membrane-spanning $\mathrm{Fc} \gamma$ receptor III isoform expressed on human placental trophoblasts. Am J Reprod Immunol 29:17-25

29. Wainwright SD, Holmes CH 1993 Distribution of Fc $\gamma$ receptors on trophoblast during human placental development: An immunohistochemical and immunoblotting study. Immunology 80:343-351

30. Niezgodka M, Mikulska J, Ugorski M, Baratynski J, Lisowski J 1981 Human placental membrane receptor for IgG. I. Studies on the properties and solubilization of the receptor. Mol Immunol 18:163-172

31. Brown PJ and Johnson PM $1981 \mathrm{Fc} \gamma$ receptor activity on isolated syncytiotrophoblast microvillous plasma membrane. Immunology 42:313-319

32. McNabb TC, Koh TY, Dorrington KJ, Painter RH 1976 Structure and function of immunoglobulin domains. V. Binding immunoglobulin $\mathrm{G}$ and fragments to placental membrane preparations. J Immunol 117:880-888

33. Rees AR, Wallace KH 1979 Approaches to structural studies on Fc receptors. In: Hemmings, WA (ed) Protein Transmission through Living Membranes. Elsevier, Amsterdam, pp 119-129

34. Lubega J $1990 \mathrm{~A}$ kinetic study of human $\mathrm{IgG}$ binding to placental Fcy-receptor. Mol Immunol 27:45-55

35. Matre R, Kleppe G, Tonder O 1981 Isolation and characterization of Fc $\gamma$ receptors from human placenta. Microbiol Scand Sect C 89:209-213

36. Makiya R, Stigbrand T 1992 Placental alkaline phosphatase has a binding site for the human immunoglobulin-G Fc portion. Eur J Biochem 205:341-345

37. Malek A, Sager R, Schneider H 1994 Maternal-fetal transport of immunoglobulin G and its subclasses during the third trimester of human pregnancy. Am J Reprod Immunol 32:8-14

38. Gitlin D, Biasucci A 1969 Development of $\gamma \mathrm{G}, \gamma \mathrm{A}, \gamma \mathrm{M}, \beta, \mathrm{A} / \beta, \mathrm{C}$, c'l-esterase inhibitor, ceruloplasmin, transferrin, hemopexin, haptoglobin, fibrinogen, plasminogen, $\alpha 1$-antitrypsin, orosomucoid, $\beta$-lipoprotein, $\alpha 2$-macroglobulin and pre-albumin in the human conceptus. $1969 \mathrm{~J}$ Clin Invest 43:1433-1438 